\title{
LAS DESNATURALIZACIONES CALCHAQUIES Y SUS EFECTOS EN LAS POBLACIONES TRASLADADAS AL VALLE DE CHOROMOROS
}

La historia de las comunidades indígenas del noroeste argentino y su evolución social se convierte - a partir de la segunda mitad del siglo XVI - en historia compartida y constreñida a un contexto más amplio que venía desarrollándose ya medio siglo antes en gran parte del continente americano: la conquista y colonización española. Este hecho fue el agente decisivo en la transformación de la historia de los pueblos aborígenes.

En la conquista y colonización de un pueblo por otro hay siempre un proceso que se repite, cualquiera que sea el escenario geográfico. Es el de la formación, en la zona conquistada, de grupos reducidos de conquistadores y colonizadores en cuyo beneficio trabajan - y generalmente mueren - grandes masas de conquistados y colonizados.

A través de los datos - bastante fragmentarios y muchas veces confusos- dejados por los cronistas, relatores, misioneros y funcionarios, además de los innumerables testimonios administrativos, judiciales y comerciales, podemos conocer acerca del mecanismo resultante de las relaciones sociales que se entablaron entre los protagonistas de las dos diferentes concepciones del mundo.

La gobernación del Tucumán nace directamente vinculada, tanto en el plano político como social y económico, al virreinato del Perú. Sin embargo, la excesiva distancia de los centros administrativos principales y la carencia de metales preciosos confiricron a la región una fisonomía propia muy peculiar que se mantuvo desde el comienzo y hasta el fin de la etapa colonial.

Los instrumentos legales por los cuales la sociedad dominante 
justificó la apropiación de los bienes de las comunidades aborígenenes fueron específicamente legitimados en cada una de las relaciones particulares. Así por ejemplo, la encomienda, la mita y el yanaconazgo regularon la forma de obtener la fuerza del trabajo indígena; el resguardo, las reducciones, la creación de «pueblos indios» permitieron la apropiación de sus tierras; las desnaturalizaciones y los extrañamientos, en fin, encubrieron la esclavitud y el despojo de todos sus bienes.

La encomienda, en particular, llegó a constituir el principio y fin económico de la clase dominante en el Tucumán.

En esta región además nacieron en un contexto histórico diferente a las del resto de la América hispana: cuando en otras jurisdicciones indianas la conquista de nuevas tierras y la «pacificación» de los aborígenes habían concluido prácticamente en el siglo XVI, en el Tucumán continuaron durante todo el siglo XVII y parte del XVII I a través de las fundaciones, refundaciones y traslados de ciudades, con la consiguiente concesión de encomiendas de indios. Su dilatada existencia —más de doscientos cincuenta años- fue uno de los rasgos peculiares que otorgó estabilidad y persistencia al poblamiento español en la región, considerando la ausencia de riquezas mineras. La encomienda se convirtió en el pilar fundamental de la supervivencia de la nueva sociedad dominante: sin metales preciosos y sin comercio en su primera etapa, las ciudades se vieron encerradas en una economía de autosubsistencia, que necesitaba de la producción aborigen para alimentarsc y abastecerse mínimamente.

Como contrapartida de esta situación la población india, afectada de diversas maneras por la colonización (explotación económica, malos tratos, epidemias, traslado de individuos a otras regiones, mestización), sufría una marcada caída demográfica y fundamentalmente la desestructuración social de sus comuniclades y la pérdida de su identidad étnica.

La encomienda en Tucumán nace oficialmente bajo el espíritu de las Leyes Nuevas de 1542 y la real cédula de 1549, es decir, la de ser una encomienda basada en la tributación indígena, de la 
cual se beneficiaban el encomendero y la Corona. Pero en la práctica se convirtió en el servicio personal que debieron prestar los aborígenes que no llegaron a tasarse, no podían concertarse ni percibían salario alguno. De hecho -y luego de derecho- la encomienda tucumana incurría en una serie de arbitrariedades por parte de los encomenderos y las mismas autoridades locales.

A pesar de la abundante legislación que se sucedió durante su primer siglo de vida, la situación no se modificó sustancialmente. Las Ordenanzas de Abreu en 1576 tuvieron un sentido protector hacia el indígena, pero el objetivo fundamental era evitar una mayor caída demográfica de las poblaciones encomendadas, que hubiera atentado contra el sistema de explotación y producción de la región. Luego, con las Ordenanzas de Alfaro de 1611, la encomienda tucumana entra a formar parte del sistema jurídico común a todo el Nuevo Mundo: se convierte en la cesión que hace la Corona a los particulares del goce de los tributos indígenas y en la pérdida de la jurisdicción que los encomenderos ejercían sobre sus indios. Ante la realidad, los efectos de esta nueva legislación no parece haber producido efectos considerables. El servicio personal siguió vigente sin mayores cambios e incluso él mismo fue el argumento esgrimido por las autoridades tucumanas para que la gobernación quedara exenta de la supresión del sistema de las encomiendas decretada a principios del siglo XVIII.

Así, pues, siendo el pilar fundamental de la subsistencia en la región del Tucumán la encomienda de servicio personal, va a ser sostenida y defendida por las autoridades locales, hasta principios del siglo XIX.

\section{ENCOMIENDA Y PRODUCCIÓN}

Para comprender los aspectos que determinaron la inserción compulsiva de las comunidades aborígenes en el sistema colonial del Tucumán — con la nefasta consecuencia de su casi extinciónes necesario analizar algunos de los complejos matices coyunturales por los que la producción regional atravesó durante más de dos siglos de vida colonial. 
Las pequeñas comunidades de españoles recién fundadas viviann limitadas a una economía natural de autosubsistencia, donde los aborígenes proveían desde las periferias rurales algunos productos que se intercambiaban en trueque de pequeña monta. Los instrumentos de trabajo y las características de la producción en este primer momento no habían variado sustancialmente de los utilizados por las poblaciones indígenas durante milenios. El cambio se produjo por la intensidad de la explotación de la mano de obra, que permitió la obtención de un volumen apreciable para la exportitción y una coyuntura apropiada que abría mercados para los productos regionales.

En menos de tres décadas de iniciada la conquista del territorio y particularmente en la década comprendida cntre 1586 y 1596, la población aborígen encomendada - la mís afectadia por el contacto con los colonizadores - sufrió una merma demográfica del $40 \%$. En ese mismo período las «ciudades» de la gobernación del Tucumán sumaron al esquema dominado por una «economíil sin mercado», una economía de cambios más complejos a gran distancia.

En una región sin metales preciosos dos factores influyeron fundamentalmente en la ambliación del universo económico de la región: el uso discrecional de la fuerza laboral indígena que $k$. permitió a la clase encomendera contar con el excedente de lia producción y el descubrimiento de las minas de Potosí en 1545. Ninguno de ellos es independiente ni excluyente de otros factores que también se conjugaron en esa coyuntura.

Las encomiendas y repartimientos de indios como formal ec()nómica y de subsistencia, permitían a los encomenderos la percep. ción de los tributos en especies o, como ocurrió en la gobernación, el servicio personal les permitió contar con una masa de individuos «disciplinados» y de escaso consumo individual, para la explotilción personal. Los indios realizaban todas las faenas que constituían la riqueza material, de consumo y comercio dentro de la provincia. Cumplían periódicamente con la mita de plaza en las ciudades para el servicio público y en las campañas atendían los ganados y trabajaban las tierras sembrando y cosechando especialmente maíz, trigo 
y algodón. De los bosques de San Miguel sacaban las maderas que en varias carpinterías de sus pueblos labraban para la construcción de casas, muebles y carretas. Hacían grandes cantidades de lienzo y conducían las carretas y arreaban las tropas de vacas y de mulas que se llevaban a vender a Potosí y al Perú.

La explotación intensiva de la mano de obra indígena comenzó al poco tiempo del descubrimiento de la plata potosina. Primero fue la extracción de los indios del Tucumán hacia Charcas y Chile (fenómeno singular que se mantendrá durante todo el período colonial), donde eran arrendados, alquilados o vendidos por el encomendero. Luego, fue la utilización de las comunidades completas (incluidas las mujeres, los niños y los ancianos) para provecr al mercado potosino de los tejidos de algodón. Finalmente, y como complemento, se utilizaban los hombres para conducir el ganado, especialmente mular, en su fase más tardía.

De esta manera el encomendero tucumano asume un tipo social de cierta complejidad en relación a esta misma clase en el resto de América. Si su jerarquía inicial había surgido de las mercedes y repartimientos con los cuales la Corona le había recompensado, su preeminencia económica, social y política es producto de diversas actividades -donde la encomienda, es cierto, siempre juega un papel fundamental- que pasan por el comercio, la agricultura, la ganadería, el transporte y la explotación de los obrajes.

El Tucumán se insertó en una economía de mercado que no significó de ninguna manera la desaparición de la economía natural, sino la coexistencia de ambas. Los encomenderos tucumanos se asociaron o se convirtieron en los mercaderes que percibían los tributos en especies como moneda natural y los vendían como productos de consumo interno o de cambio en el mercado interregional, cobrando por ellos en moneda metálica o, en su defecto, en moneda de la tierra, es decir, en especies (maíz, trigo, algodón, lienzo, etc.). Cada ciudad había establecido su propia moneda de la tierra, pero siempre equivalente a la plata de ocho reales. De todos modos, ello los favorecía ampliamente en la acumulación de capital.

Sin embargo, a partir de la segunda mitad del siglo XVII se 
advierte en el Tucumán una importante depresión económica directamente vinculada a la caída de la producción minera del Potosí y a la grave disminución demográfica de la mayor parte de los pucblos aborígenes encomendados.

Estos factores aunados provocarán en 1659 y 1665 una nuevil etapa de conquista, en este caso, de las poblaciones indígenas calchaquíes que aún en este período se encontraban «marginadas» del sistema colonial. Si las anteriores guerras calchaquíes habían tenido un carácter más bien defensivo para el español, hacia el siglo XVII el belicismo indígena había decaído. Pero una serie de elementos volverán a conjugarse para atentar contra el último reducto de resistencia aborigen dentro de la región: especialmente la aparición de un español aventurero, dispuesto a sacar provecho de la sitllación de rebeldía de los indígenas, y la caída demograífical de las poblaciones encomendadas que obligaba a lograr la sujeción de esia masa de indios que aunque «estaban encomendados, no acudían los más dellos a las rentas y servicio personal dispuesto por ordenanzas».

Es entonces cuando se abre otra etapa en el Tucumán. Si bien el Potosí ha perdido gran parte de su capacidad estimulante, (l) comercio de la gobernación -especialmente de mulas- no decac. Más bien se mantiene parejo hasta mediados del siglo XIX, convirtiéndose en una importante fuente de ingresos para toda la región. Por otro lado, la jurisdicción recibe una «inyección» de nuevas masas indígenas (a las que luego se suman las poblaciones chaqueñas), que sirven de mano de obra para obtener las granjerías de la región. Nuevos encomenderos se sumaron al grupo de feudatarios ya existentes.

Sin embargo, a fines del siglo XVII el descenso demográlico que se venía produciendo continúa con su curva de ritmo descendente. El hundimiento general de la población aborigen del Tucumán es, en las últimas décadas, de casi un $55 \%$, sobresaliendo la de San Miguel con un $60 \%$. Sus causas siguen siendo, en líneas generales, las pestes, los malos tratos y la extracción de individuos hacia otras regiones. Pero en este caso en particular, tuvo especial incidencia en la velocidad de la extinción de algunas co- 
munidades, la política dispuesta por las autoridades locales sobre el extrañamiento y la desmembración de los grupos repartidos en varias encomiendas, distorsionando la unidad familiar y exigiendo el mismo rendimiento laboral a los pequeños feudos y a los mayores.

Durante el siglo XVIII la actividad fundamental de la región seguirá siendo el comercio y la ganadería, sumada a una mayor diversificación agrícola, pero en general ya amenazados por los primeros embates del comercio libre institucionalizado lentamente desde el reinado de los Borbones. Sin embargo, la ventajosa ubicación de la gobernación le permite actuar de mediadora entre el puerto de Buenos Aires y el litoral argentino - mercado especialmente óptimo para la industria maderera- y una avanzada en el impulso comercial porteño hacia el Alto Perú.

En esta última coyuntura colonial, los miembros de las poblaciones aborígenes que han logrado sobrevivir se han convertido en peones forzados en las estancias o en las nuevas ciudades interiores que han ido surgiendo, en una situación de más o menos concertaje, mal pagados y discriminados por la sociedad dominante.

\section{El. Vaille de Chioromoros}

El proceso de la desestructuración social y étnica de las comunidades indígenas — producto de las relaciones impuestas por el mundo colonial - ha sido analizado en su magnitud más aproximada en este trabajo en un distrito concreto de la jurisdicción de San Miguel del Tucumán, exactamente el correspondiente al valle de los Choromoros, y durante un período de tiempo también concreto, el siglo XVII.

Si el proyecto inicial tuvo como objetivo primordial la identificación de las poblaciones aborígenes originarias de la zona y su posterior inserción en la estructura de la conquista, el desarrollo alcanzado por la investigación nos permitió a su vez proceder al estudio de todo lo referente a la ocupación territorial por parte del indígena y del español, así como a conocer su situación demo- 
gráfica, cultural y jurídica. A partir de los resultados obtenidos creemos que es factible el análisis objetivo de algunos aspectos del proceso desencadenado por las relaciones interétnicas en la región.

Comprendemos bajo el nombre de «valle de los Choromoros» al área geográfica - mucho más amplia que la actual- que hasta el siglo XVIII conformaba uno de los tres distritos en que se dividía la jurisdicción de San Miguel de Tucumán, e incluía a los actuales departamentos de Trancas, Burruyacu, parte de Tafí y la capital, en Tucumán, y zonas aledañas de Salta y Santiago del Estero.

Dentro de esa extensa área, la cuenca conocida como TapiaTrancas, enmarcada entre las sierras subandinas por el este y las cumbres Calchaquíes por el oeste y atravesada de norte a sur por el río Salí, ha actuado a lo largo del tiempo con mecanismos propios de una frontera cultural. Ya desde el período prehispánico las características geomorfológicas de la cuenca y sus numerosas vías naturales de comunicación, permitieron la confluencia de grupos aborígenes procedentes del valle de Santa María y Calchaquí y otros provenientes de las llanuras orientales. Durante el período colonial, su fácil tránsito en dirección norte-sur convirtió al valle en camino obligado para unir los territorios del Plata con Potosí.

Ciento treinta años de rebeliones calchaquíes modelaron la fisonomía de ocupación de la región. La imposibilidad del español de ejercer un efectivo control del valle Calchaquí mantuvo a Choromoros como frontera militar y campamento de las fuerzas coloniales. Finalizada la guerra y volcados los esfuerzos de conquista hacia el frente oriental, el valle de Choromoros siguió sujeto a las exigencias de aportar su población para volver a defender la frontera.

Como primer objetivo de la investigación se intentó cubrir un lapso temporal desconocido de la historia del valle. Corresponde a las primeras décadas del siglo XVII, enmarcadas por la ocupación española y la incorporación de las poblaciones calchaquíes trasladadas a la zona. 
Las particularidades de la encomienda en la gobernación del Tucumán, cuyas prestaciones mediante el servicio personal provocaron una situación de mayor dispersión, mestizaje y aculturación dieron como resultado la fragmentarización y debilitamiento de las unidades étnicas, pero no ya como resultado de una natural tendencia de contactos interétnicos, sino fruto de la política colonial.

En el proceso de ocupación del territorio, la fundación de las ciudades fue una necesidad estratégica que pretendía mantener la relación de intercambio económico entre el Perú y la gobernación del Tucumán. En ese esquema poblacional el valle de Choromoros formaba parte del área «rural» subsidiaria de la ciudad cabecera. El papel a cumplir era el de formar un cerco fronterizo alrededor de los valles Calchaquíes y asegurar ese tramo del «camino del Perú».

La ocupación del valle de Choromoros durante el período colonial no fue efectiva sino hasta mediados del siglo XVIII, ya que su población - tanto europea como aborigen - estuvo sujeta a las exigencias que imponía la defensa de los dos frentes bélicos.

Las características etnográficas de las poblaciones indígenas de la región responden a los patrones culturales de poblaciones semisedentarias o nómadas que no se tasan y se los incorpora legalmente al servicio personal de los encomenderos «porque no producen nada para tributar».

A principios del siglo XVII las parcialidades indígenas efectivamente encomendadas en el valle apenas superaban la media docena, adjudicándolo a una probable baja densidad demográfica fruto en parte de los peligros que la zona revestía por los ataques de calchaquíes y mocovíes.

Es evidente también un marcado proceso de desnaturalización de las comunidades trasladadas desde sus asientos originarios hacia las estancias de los encomenderos. Ello implicaba readaptaciones ecológicas que alteraban las condiciones de vida de los pueblos involucrados lo que, unido al tipo de tareas obligadas a realizar, los malos tratos, epidemias, alteraciones en los mecanismos de producción y reproducción, inlluyó en la densidad demográfica. 
Al analizar las arbitrariedades con que se aplicaron las leyes en el Tucumán de los siglos XVI y XVII, se comprende quizás mejor la realidad espacio-temporal en que se inserta la región: una gobernación marginal de las áreas neurálgicas del imperio hispano, sin minas ni riquezas de ese tipo, y en un proceso tardío de conquista y colonización que no por ello fue mejor ni más justo, sino todo lo contrario.

Este último aspecto se evidencia particularmente en la «legalización» de las desnaturalizaciones con ocasión de la finalización de las guerras calchaquíes.

Los distintos sistemas que impuso el español para la organización del trabajo indígena, la estrategia utilizada para integrar a los naturales a las pautas de vida determinadas por el «orden y policía», la imposición de creencias religiosas y la mecánica de control sobre la vida cotidiana, dieron por resultado la ruptura de la estructura original de la sociedad aborígen, secundada por una legislación tendente a imponer por la fuerza la nueva cosmovisión dominante.

Un mecanismo de amplio desarrollo en la gobernación del Tucumán que atacó a la base misma de la sociedad aborigen fue el de las «desnaturalizaciones» (erradicación de los grupos indígenas de sus nichos ecológicos originales). Producto en parte de las constantes luchas contra los indios calchaquíes y los del Chaco, sus antecedentes pueden rastrearse desde los comienzos de la colonización del territorio.

Continuando con la investigación que atañe a la dinámica de ocupación del valle de Choromoros durante el período colonial y sus implicaciones demográfica, social y cultural para las comunidades aborígenes de la zona, se centra el análisis de este trabajo en las poblaciones indígenas extrañadas de Calchaquí y ubicadas en Choromoros y las consecuencias que tal procedimiento engendró.

Más de un siglo de rebeliones chalchaquíes modelaron la estructura ocupacional de la región. La imposibilidad del español de ejercer un efectivo control del valle calchaquí, mantuvo a la población de Choromoros en constante peligro. Dominadas las pobla- 
ciones rebeldes por las fuerzas militares coloniales, el gobernador Mercado y Villacorta procedió a las desnaturalizaciones masivas de 1659 y 1665 , para «corregir lo notorio de sus delitos y regirlos y conservarlos en el dictamen de verdaderos cristianos». Ello dio como resultado la descomposición y ruptura de las pocas unidades étnicas que se conservaban como tales en la región. Divididos los pueblos en innumerables encomiendas o repartidos como «piezas» entre los soldados que intervinieron en la guerra, son separados en definitiva de sus tierras, de sus familias y de sus tradiciones.

\section{ESTADO DE LA CUES'TIÓN Y FUENTES CONSULTADAS}

Pocos autores se abocaron al tratamiento de la problemática de las desnaturalizaciones de las poblaciones calchaquíes y quienes lo han abordado lo hicieron desde las perspectivas casi exclusivas del colonizador, examinando los efectos que el procedimiento tuvo para el desarrollo de las ciudades españolas, o en su defecto, reinterpretando sus consecuencias de manera general para todas las poblaciones aborígenes de la gobernación del Tucumán. ${ }^{1}$

En cuanto a los testimonios que hacen referencia a las poblaciones calchaquíes desnaturalizadas son en general de carácter militar y eclesiástico, emanados de los gobernadores o vecinos que participaron en la contienda y de los clérigos que actuaron de mi-

1 El tema de las guerras calchaquíes y las consecuentes desnaturalizaciones de los pueblos aborigenes puede ser consultado en: Lozano, P.: Historia de la conquista del Paraguay, Río de la Plata y Tucumán. Buenos Aires, 1875; Torre Revello, José: La memoria del primer gobierno de Mercado y Villacorta en Tucumán (1655-1660). «Boletín del Instituto de Investigaciones Históricas de Buenos Aires». tomo 25, núm. 85 88, Buenos Aires, 1940-1941; Montes, Aníbal: El gran alzamiento diaguita (1630-1634). «Revista del Instituto de Antropología, Universidad Nacional», tomo I, Rosario, 1959; Fernaindez de Sachorr, Adela: El segundo levantamiento calchaquí. Tucumán, 1968; Piossek Prebish, Teresa: La rebelión de Pedro Bohórquez. El Inca de Tucumán. (1656-1659). Buenos Aires, 1976; Ottonello, M. M. y Lorandi, A. M.: Introducción a la Arqueología y Etnología Argentina: 10.000 años de Historia. Buenos Aires, 1987. Además hemos tenido acceso a los trabajos inéditos de: Lorandi, A. M. y Ferreiro, J. P.: De la crisis a la estabilidad. La sociedad nativa en Tucumán a fines del siglo XVII y comienzos del XVIII, y Lorandi, A. M.: Los trabajos y las rebeliones en el Tucumán colonial. Vaya desde aquí nuestro agradecimiento a ambos autores por habernos permitido la consulta de sus trabajos. 
sioneros en la región. Al finalizar la guerra todos coinciden en los argumentos a favor de los extrañamientos, a pesar de los efectos poco redituables que tal medida tenía desde el punto de vista de la producción aborigen. ${ }^{2}$

Una vez extrañadas las poblaciones del valle y encomendadas a vecinos de la gobernación del Tucumán e inclusive de Buenos Aires y Santa $\mathrm{Fe}$, comenzaron a ser registradas por los padrones que se conservan para la segunda mitad del siglo XVII. Todo ello sucedió en virtud de que, en 1668, la audiencia de Buenos Aires había hecho pública una real cédula por la cual se ordenaba para todo el territorio americano «expresar siempre en los títulos el verdadero valor de la encomienda y el número de naturales sujetos a cada encomienda con distinción de sexos y edades». "

Las encomiendas otorgadas por Mercado y Villacorta a los vecinos feudatarios de la región debieron ajustarse a esta nueva legislación, por lo que se puede contar con una mayor cantidad y calidad en la documentación de este período.

Esa documentación consiste fundamentalmente en empadronamientos de pueblos indios y encomiendas de las distintas jurisdicciones de la gobernación del Tucumán y algunas visitas generale's y circunstanciales que se conservan para la zona.

Con respecto a los padrones podemos establecer que al ser realizados en general con propósitos fiscales, o sea el de constatar el cumplimiento de la tasación indígena o el de exigir a los encomenderos el pago de la media annata, carecen de detalles que permitan determinar las condiciones a las que se hallaban sujetos los encomendados. Lo que sí puede inferirse a través de ellos es el hecho de que el sistema de la encomienda en Tucumán - legalmente de tributos, pero en la práctica de servicio personal - no había variado hacia fines del siglo XVII y principios del XVIII: las enco-

2 Las mismas medidas tomadas luego del gran alzamiento calchaqui de 1630 , con respecto a las poblaciones de hualfines, andalgalás y abaucán habían demostrdo el poco rendimiento del trabajo indígena bajo las nuevas condiciones impuestas (ver: Montes, A.: El gran alzamiento...).

3 Real cédula fechada en Madrid, 10 de mayo de 1667. Citada por González Rodriguez, Adolfo L.: La encomienda en Tucumán. Sevilla, 1984, pág. 112. 
miendas siguen localizadas en los terrenos de los españoles y hay una falta total de recuentos tributarios.

En cuanto a las fuentes de carácter general sólo se conservan para la región, la relación de encomiendas y padrón ordenada por el gobernador Angel de Peredo en el año 1673, que cubrió tanto a la gobernación del Tucumán como a la de Buenos Aires, y la visita general de la tierra llevada a cabo por el oidor Antonio Martínez Luján de Vargas durante los años 1692 y 1694.

Si bien existía la necesidad siempre vigente de la retasación de la población aborigen y constantes denuncias sobre las malos tratos e irregularidades que se cometían con las encomiendas tucumanas - que ameritaban las visitas y empadronamientos generales en la gobernación-, los obstáculos que en la práctica encontró el cumplimiento de ellos los redujo a los dos casos mencionados. Aunque su valor testimonial es indiscutible, requiere un tratamiento metodológico especial para cada caso.

Finalmente contamos para realizar esta investigación con dos visitas eclesiásticas al curato de Colalao, efectuadas en 1680 y 1683 , que hacen referencia a las condiciones de los pueblos indígenas de Colalao y Tolombón en sus asentamientos de Choromoros.

\section{El valle de ios Choromoros ante I.AS REBEIIONES CAICHAQUÍES}

A pesar de que los valles de Calchaquí y Choromoros se hallan separados por las elevadas cumbres Calchaquíes, los numerosos pasos que los atraviesan han permitido contactos e influencias culturales entre las poblaciones de ambas vertientes ya desde el período prehispánico. Es más, al iniciarse la ocupación española en el valle de Choromoros, a principios del siglos XVII, algunas poblaciones serranas ya habían sido incluso otorgadas en encomienda a vecinos de la región aunque efectivamente no cumplieran con las prestaciones acordadas.

A su vez la precariedad de los asentamientos españoles en la región de los Choromoros durante el sigo XVII y la resistencia 
de algunos grupos encomendados de la zona - muchos de los cuales escapaban de las reducciones y huían a los cerros-, permitió varios ataques calchaquíes a la región, para lo cual utilizaban los pasos que secularmente habían unido a los valles. Esto provocó la actitud de parte de las autoridades tucumanas de crear un cerco alrededor de las poblaciones rebeldes que incluía al valle de Choromoros y al valle de Salta, convirtiéndose, pues, esta zona en una de las más afectadas por las contiendas.

Así en vísperas del primer gran alzamiento (1629), los indios de Calchaquí fueron acusados de «nuevas culpas y atrocidades» en el valle de Choromoros, pues llegaron «hasta salir a los caminos reales, doblando la cordillera y haciendo diferentes muertes y robos en las estancias circunvecinas». ${ }^{4} \mathrm{Y}$ momentos antes de la rebelión de Pedro Bohórquez, exactamente en mayo de 1653, el alcalde ordinario de San Miguel de Tucumán don Diego García Valdez exigía que se labrara un auto para investigar sobre unas cartas enviadas por el capitán Juan de Escobar, vecino del valle de Choromoros, donde anunciaba que los indios del valle Calchaquí y Yocavil «no están buenos ni de paz» porque se lo han dicho los indios de su encomienda, indios de Tafí «que algunos de ellos los tienen en el dicho valle de los Choromoros». ${ }^{5}$ Por otro lado, y de acuerdo al mismo testimonio, puede inducirse que la actitud de los calchaquíes obedece a la incitación provocada por un vecino de San Miguel que tenía interés en quedarse con el producto del trabajo de los naturales.

La rebelión de los indígenas en este caso, no sólo hacia a la posibilidad del peligro de un ataque - lo que en esta época ya era casi un hecho- sino también a la imposibilidad de contar con la mano de obra necesaria para el trabajo diario en las estancias ya que los aborígenes se resistían a cumplir con la mita. Esa resistencia de los naturales a ser absorbidos por el sistema colonial,

4 Carta del gobernador de Tucumán, don Felipe de Albornoz a S. M. dando cuenta de los delitos cometidos por los indios de Calchaquí. Santiago del Estero, 7 de setiembre de 1631. En: Larrouy, P. Antonio: Documentos del Archivo de Indias para la Historia del Tucumán. Buenos Aires, 1923, tomo I, docum. núm. XI.

5 Lizondo Borda, Manuel: Documentos coloniales relativos a la ciudad de San Miouel de Tucumán. Siglo XVII. Tucumán, 1937, Serie I, vol. II, documento V. 
decisión tomada por sí mismos o por influencisa de algunos españoles interesados en la situación, hablaba a las claras sobre el hecho de que las encomiendas - realmente no efectivas - no producían lo que sus destinatarios exigían.

La necesidad de pacificar el valle era un imperativo. $\mathrm{Y}$ el castigo al segundo gran alzamiento será más drástico aún que el primero. Entre 1659 y 1665 prácticamente todas las parcialidades de Calchaquí fueron desarraigadas y el valle despoblado, por lo que el gobernador Mercado y Villacorta «dio licencia, en nombre de Su Majestad, para que los españoles las pidieran en merced, tierras, aguadas, etc. para formar en ellas estancias y poblaciones. Así lo hicicron muchos y ahora las tierras de Calchaquí están habitadas por ellos»."

UN CASO DE «DESNA'TURALIZACIÓN»:

el pueblo de Colpes

La situación legal del indio, la modalidad laboral que adquirió en la gobernación del Tucumán y el uso y tenencia de las tierras son aspectos parciales de un mismo problema, que reflejan la realidad colonial.

En algunos centros de la colonización hispana, como es el caso de Potosí, condicionaban y establecían las pautas a seguir por las regiones subsidiarias como lo era el noroeste argentino. La legislación protectora de sus intereses trató de evitar por todos los medios la «desnaturalización» de los indios ubicados en las proximidades de las minas. ${ }^{7}$ Sin embargo no existieron trabas respecto a trasladar otros pueblos de regiones más alejadas hacia esos centros, como ocurrió en gran medida con las poblaciones de la gobernación del Tucumán.

6 Torreblanca, P. Hernando de: Relación de los sucesos que tuvieron lugar en la misión de los Calchaquies en el año 1636. mientras estaba en ella el padre... de la Compañia de Jesus.s. Transcripción y nolas de Teresa Piossek Prebish (el manuscrito fue gentilmente facilitad• por su autora).

7 Rodríguez Molas, Ricardo: Los sometidos de la conquista. Buenos Aires. 1985, págs. 125-147. 
Pero no sólo con el propósito de ser trasladados hacia el Alto Perú fueron desnaturalizados los aborígenes de estas provincias. Con la justificación de un razonamiento que pretendía «adoctrinarlos, tener un mejor control de la mano de obra, evitar la dispersión», o para «ubicarlos en mejores tierras» que sus asentamientos originarios, algunos indígenas, familias y a veces pueblos completos fueron ubicados en los establecimientos españoles, imponiéndose de hecho una situación laboral de servicio personal. Las modalidades de este tipo de prestaciones fueron legisladas a lo largo del siglo XVI y comienzos del XVII. Primeramente las ordenanzas de Toledo, luego las de Abreu y finalmente las de Alfaro terminaron legalizando una situación que de hecho se venía dando: el desarraigo y la servidumbre. ${ }^{8}$

Las ordenanzas de Alfaro tienden específicamente a preservar al indio en su comunidad. Con ello se pretendía de algún modo poner fin a las arbitrariedades de los encomenderos tucumanos que desplazaban a los indios de sus lugares originarios a otros, con la finalidad exclusiva de pretender algún día la posesión y propiedad de las tierras en que se había asentado la comunidad de los naturales. El íntimo propósito del oidor era el de garantizar la permanencia de los naturales en sus asentamientos y la defensa de sus propiedades para asegurar su producción y tributación. Claro que estas medidas no eran novedosas dentro de la ya tradicional política de la Corona que establecía que para empadronar a los aborígenes instalados en las haciendas españolas se procedería a naturalizarlos y concederles las tierras que ocupaban. Es obvio que esa «concesión» de tierras y la consiguiente reducción a pueblo que implicaba la ordenanza atentaba contra los intereses de los encomenderos - al mismo tiempo hacendados- en los posibles derechos de uso y propiedad que hasta ese momento hubieran tenido. La ley, más taxativa aún, establecía que los ganados de los españoles debían estar a no menos de tres leguas de distancia de los pueblos de indios y los indios sólo podrían sembrar en las tierras

8 Las Ordenanzas de Alfaro han sido transcriptas por Levillier, Roberto: Correspondencia de la ciudad de Buenos Aires con los Reyes de España. Buenos Aires- Madrid, 1915-1918, 3 vols. 
de sus pueblos (ordenanzas 34 y 38). De ahí que la negación del carácter de pueblo de algunos grupos aborígenes por parte de los encomenderos era muy conveniente para el aprovechamiento de las tierras indígenas, cuando no la posibilidad de agregarse esas tierras al patrimonio privado al denunciarlas como «yermas y despobladas».

Unida a la posibilidad real de la pérdida de sus tierras, la situación legal y laboral de los aborígenes desnaturalizados era peor aún. El indio reducido a encomienda revestía el carácter de tal mientras no era movido de su pueblo, seguía sujeto a su cacique y residía en el repartimiento de su naturaleza. Según Zavala, ${ }^{9}$ en la encomienda de pueblo, llamada también de cacique, los naturales permanecían en sus tierras, no así en las encomiendas de «indios sueltos o piezas». Este último tipo de encomienda, prohibida por las Ordenanzas 3 y 4 de Alfaro, fue bastante frecuente en la gobernación de Tucumán, y finalmente legalizada por Mercado en 1659. En esa ocasión se repartieron mil «piezas de indios que lucharon hasta el final, entre los encomenderos, capitanes y soldados que habían intervenido en la guerra y ciento cincuenta se reservaron para los conventos, viudas y pobres». ${ }^{10}$

Cuando un grupo de aborígenes, pueblo o parcialidad era trasladado de su asiento originario, quedaba marginado de la legislación que reglamentaba su condición laboral. No revestía el carácter de indio encomendado (no en el sentido estricto, aunque conserva csa denominación), ni de yanacona, pues aquéllos eran contratados en servicio personal, aunque luego el concepto se deformara designando como yanaconas a todas las prácticas de servicio personal de los indios encomendados legalmente prohibidas por la legislación general; ${ }^{11}$ ni tampoco se le puede considerar indio mitayo, pues no se trataba de aborígenes que residían intermitentementc y por turnos en las haciendas españolas, sino en forma permanente en las propiedades de su encomendero, sin regresar a sus repartimientos de origen. La situación nunca es clara, pero la desvirtua-

9 Zavala. Silvio: La encomienda indiana. México, 1973.

10 Carta del gobernador Alonso de Mercado sobre el número de indios prisioneros en la guerra de Calchaquí y del modo como se repartieron. Buenos Aires, 5 de mayo de 1661. En Larrouy, P. A.: Documentos..., docum. núm. XXIX.

11 Lorandi, A. M.: Los trabajos y... 
ción de las instituciones laborales vigentes en América, dio como resultado en el Tucumán la implantación del servicio personal. $\mathrm{Y}$ con ello se producía la desarticulación de la sociedad aborigen, pues separados en encomiendas de unas pocas familias no tenían oportunidad de conservar ningún tipo de mecanismo social original de su etnia.

Un caso concreto de esa situación podemos verlo en el pueblo de Colpes. Una parte de él la encontramos relocalizada en el valle de Choromoros hacia fines del siglo XVII. Investigando sobre el origen y antiguo asentamiento de este pueblo, nos encontramos ante un caso de desposesión de tierras y posterior desnaturalización.

En el año 1608, los indios del pueblo de Colpes venden sus tierras a don Juan Martínez de Iriarte, quien las había ocupado «con ganados mayor y menor» aduciendo que le habían sido otorgadas por merced del gobernador. Los aborígenes, asesorados por el protector de naturales y «por bien de paz y quitarnos de pleito, debates y diferencias por ser sus fines dudosos y inciertos hemos tratado de vender las dichas tierras y el derecho de acción que a ella tenemos al dicho Juan de Iriarte», incluyendo como lo establece el mismo testimonio tierras de pastura y tierras para cultivos. ${ }^{12}$ Sin que hubiese en ningún momento mediación del encomendero de este pueblo - don Gaspar Doncel- los indios vendieron sus bienes «por precio y cuantía de doscientas ovejas de Castilla», considerándolo precio «justo» pues nadie ofreció más.

A pesar de que las tierras de indios eran inalienables según la legislación vigente, la demanda de Iriarte procede y se le adjudican los bienes reclamados.

Según las Ordenanzas de Alfaro, relacionadas con la delimitación de las tierras que debían constituir la base patrimonial del pueblo de indios (Ordenanzas 33 y 34), se establecía un espacio territorial libre de toda vinculación patrimonial privada, el que cercando a los pueblos de indios constituyera un medio de defensa respecto a su integridad y a su derecho de propiedad o posesión

12 Archivo Histórico de Tucumán (en aclelante A.H.T.), Serie A. Protocolos 1; fols. 393v.-396. En: Lizondo Borda, Manuel: Documentos..., docum. núm. LXVII. 
frente a los posibles abusos de vecinos españoles que extendiendo sus chacras y estancias podían atentar contra la subsistencia de aquellos pueblos.

Este tipo de legislación incurría en una contradicción interna si se considera el caso de los pueblos y reducciones de indios que se constituyen en las tierras de los encomenderos. Tarde o temprano, éstos o sus descendientes pretenden el pleno ejercicio de sus derechos a la propiedad de esas tierras. Este tipo de situaciones será muy frecuente luego de las desnaturalizaciones masivas de 1659 y 1665.

En el año 1611 el pueblo de Colpes, aparentemente desmembrado al menos en dos repartimientos, aparece como encomienda de doña Juana de Villegas, a quien había pasado por derecho sucesorio de su primer marido, el capitán Diego de Vera. ${ }^{13}$ En 1612 el segundo marido de doña Juana de Villegas obtiene una merced de tierras otorgada por Alonso de Ribera, ubicadas en «la otra banda de la cuesta de Paquilingasta» «que es la misma que poseyó Diego de Vera», y allí se establece como cláusula especial «que los indios sean preferidos en las mejores tierras y primera agua de las acequias a su escogencia». ${ }^{14} \mathrm{Si}$ esta cláusula se cumplió no podemos asegurarlo. Es probable que respondiera simplemente a una formalidad administrativa.

Separado en dos parcialidades el pueblo de Colpes aparece registrado en los padrones de indios realizados en las distintas jurisdicciones tucumanas por orden del gobernador Angel de Peredo en 1673. ${ }^{15}$ En San Juan de la Ribera de Londres el repartimiento aparece registrado como encomienda de Juan Bernardo de Nieva y Castilla y contaba con 26 tributarios, 13 reservados, 21 muchachos,

13 A.H.T. Serie A; Protoc. 2; fols. 54-55. En: Lizondo Borda, M.: Documentos coloniales.... Serie I, vol. III, docum. núm. VII.

14 A.H.T., Serie A; Protoc. 1; fols. 354 y v. En: Lizondo Borda, M.: Documentos coloniales.... Serie I, vol. II, docum. núm. LVII.

15 Los resultados del empadronamiento de 1673 han sido publicados por Ravignani, E.: La población indígena de las regiones del Río de la Plata y Tucumán en la segunda mitad del siglo XVII. «Actas y trabajos cientiflcos del XXV Congreso Internacional de Americanistas». Buenos Aires, 1932, págs. 295-305; y por González Rodríguez, A.: La encomienda..., Apéndice I. 
36 chinas y 12 viudas. En la ciudad de San Miguel de Tucumán liı otra parcialidad de los Colpes estaba encomendada a Andrés Ahumada y contaba con su curaca, 5 tributarios ausentes, 1 reservado, 9 muchachos y 5 chinas.

Según la tasación de indios hecha por el oidor don Antonio Martínez Luján de Vargas, con motivo de la visita general que llevó a cabo en la gobernación de Tucumán entre 1692 y $1694,{ }^{16}$ la población de Colpes se registra encomendada a Esteban de Nieva y Castilla, vecino de Catamarca (donde reside el pueblo), y cuenta con 19 tributarios. Este encomendero la gozaba en tercera vida pues la familia Nieva y Castilla poseía esta encomienda desde $1643 .{ }^{17}$

Para esta misma fecha el empadronamiento de San Miguel de Tucumán no registra al pueblo de Colpes. Sin embargo, según la descripción que don Alonso Ruiz de Marañón, cura de Colalao, hace de su curato en 1692 un grupo de indios colpes está radicado en Choromoros, como encomienda de don Juan de Palacios que cuenta con 8 indios tributarios. Palacios era descendiente de la familia Martínez de Iriarte, heredera a su vez de las propiedades adquiridas por don Juan Martínez de Iriarte, es decir las tierras de los colpes. ${ }^{18}$ Es probable que los indios de esta población hubieran permanecido en sus antiguas tierras hasta ser trasladados a Choromoros o bien que su traslado sea resultado de los extrañamientos realizados por Mercado y «casualmente» fueran encomen-

16 El empadronamiento de las poblaciones indigenas registradas por la visita general de 1692 ha sido transcripto por Doucet. Gastón: Introducción al estudio de la visita del Oidor Don Antonio Martinez Luján de Vargas a la Encomienda del Tucumán. «Boletín del Instituto de Historia Argentina y Americana», Año XVI. tomo XVI, núm. 26, págs. 205-247, Buenos Aires, 1980; y por González Rodríguez, A.: La encomienda..., Apéndice II.

17 González Rodríguez ( La encomienda..., pág. 258) consigna que la encomienda de Colpes, Colana. Mutquin y anejos era posesión de Francisco de Nieva y Castilla en 1643, con 25 tributarios; de Juan de Nieva y Castilla en 1673, con 26 tributarios, y de Esteban de Nieva y Castilla entre 1693 y 1719 , con 17 indios tributarios.

18 Don Juan de Palacios y Martinez de Iriarte era descendiente del sargento mayor don Francisco de Palacios, natural de España, y de doña Francisca Martínez de Iriarte. A su vez, estuvo casado con doña Juana Ruiz de los Llanos y Albarración. natural de Salta y propietaria de los terrenos que actualmente llevan su nombre. Citado por Zenarruza, Jorge G.C.: Tercera Fundación de la ciudad de S.S. de Jujuy. Buenos Aires, 1980, págs. 330-331. 
dados en Juan de Palacios. Lamentablemente la documentación que se conserva al respecto no nos permite aclarar la situación.

Luego de estos registros del pueblo de Colpes realizados a fines del siglo XVII, no son consignados en ningún otro testimonio sobre empadronamientos de indios de la jurisdicción de San Miguel de Tucumán. Es probable que esta población ya estuviera en vías de extinción o de aculturación con otros grupos étnicos. Juan de Palacios era también en 1692 encomendero del pueblo de Anganomo, otra encomienda muy reducida en esa época (ver apéndice, cuadro V).

La flexibilización de las pautas matrimoniales y de las relaciones interétnicas en general, provocadas por la misma situación de desarraigo y desestructuración social, atentaría contra la identidad grupal y terminaría por incluir a los integrantes de los distintos pueblos en una única categoría de indios. Por otro lado es necesario tomar en cuenta también el acelerado proceso de mestización que se va produciendo, elemento que no sólo modificaría la categoría étnica de los pueblos indígenas sino también su condición social y fiscal.

LAS DESNATURALIZACIONES CALChaquíES:

Chuschagastas, Tolombones, Colalaos

\section{a) Sus extrañamientos}

Sin lugar a dudas los traslados y desnaturalizaciones aplicadas como castigos a las rebeliones calchaquíes son los que tuvieron los efectos más devastadores y dramáticos para las poblaciones involucradas, provocando una absoluta desestabilización social.

Pueblos completos fueron extrañados pero raras veces fueron ubicados en su totalidad en un mismo asentamiento. La mayoría de las poblaciones fueron divididas entre varios encomenderos, sin que se pueda determinar a través de la documentación, cuál fue el criterio utilizado en esa separación. Quizá respondiera a alguna división interna dentro de cada grupo étnico o fuera simplemente 
una relación de cantidad de familias aborígenes según el mérito del encomendero. Otros individuos fueron entregados como «piezas» para el servicio personal de los soldados. Si hubo en algún momento jefaturas más o menos abarcadoras de varios pueblos, las desnaturalizaciones terminaron por desmembrarlas. Los españoles consideraron que esa política seguida era la única válida para finalizar definitivamente con el peligro calchaquí e iniciar el ansiado período de paz en la gobernación.

Hacia mediados del siglo XVII, que coincidía con más de un siglo de rebeldía aborigen en los valles del oeste, el declive de la economía tucumana era inevitable, de no ponerle fin al conflicto. Así la coyuntura potosina que le había permitido al Tucumán insertar los productos regionales (algodón, tejidos, ganados, cera, miel), y obtener un excedente monetario, ya había entrado en crisis. Las numerosas aduanas interiores trababan el comercio de la zona; y fundamentalmente, la vertiginosa caída demográfica de las encomiendas de la jurisdicción condicionaban a poner en movimiento los mecanismos militares de toda la gobernación, esta vez no sólo con carácter defensivo sino como una «gran empresa económica», es decir, había que obtener la mano de obra necesaria para seguir haciendo producir las chacras, estancias y haciendas.

Según el gobernador Albornoz, el número de naturales cue habitaban el valle calchaquí hacia 1630 era de unos 12.000 individuos que incluían niños, mujeres y ancianos. ${ }^{19}$ Esa cantidad parcece haberse elevado hacia 1659, cuando se produce el segundo levantamiento, pues según el informe de Pedro Bohórquez, los indios que tomaron las armas y se unieron a la rebelión contra los españoles eran unos 3.500 de armas y unos 17.000 en total. ${ }^{20}$ Entre ellos, los Chucagasta ( $\mathrm{sic}$ ) y las parcialidades Talampun (Tolombón) y Colalao sumaban 370 indios de armas y aproximadamente 1.800 almas. No todos esos aborígenes pasaron desnaturalizados a Choro-

19 Carta del gobernador Albornoz sobre el alzamiento de los calchaquies. Santiago del Estero, 16 de abril de 1630. En: Larrouy, P. A.: Documentos..., docum. núm. VIII.

20 A.G.1., Charcas, 121. Informe de Pedro Bohórquez, cit. por González Rodrí guez, La encomienda..., pág. 27. 
moros ya que muchos murieron en el combate, huyeron o se suicidaron antes de caer cautivos.

El pueblo grande de Tolombón y el de los paccioca fueron las primeras parcialidades calchaquíes en ser vencidas por los españoles en la campaña de 1659 e inmediatamente reducidos a obediencia. Los indios rindieron sus armas y solicitaron al gobernador que liberara sus prisioneros (especialmente mujeres). La respuesta fue «...que si traían igual número de cautivos tomados entre los indios aún rebeldes y los encerraban en la prisión, podrían retirar a los prisioneros hechos en su pueblo...». Con ello Mercado procedía a aplicar la política de romper con «la amistad que hasta entonces había mantenido unidas a las tribus calchaquíes». ${ }^{21}$

Esa política de «indios amigos» utilizada por los españoles les permitió contar con una masa importante de gente para el ejército y para repartirlos luego para el servicio personal entre los soldados que habían participado en la guerra. Para las comunidades indígenas haber acordado la paz no significaba de ninguna manera mejorar sus condiciones de sujeción: «...pueblos enteros se presentaron ante el gobernador para darle la paz y él la admitió con la condición de que abandonaran el valle de Calchaquí y se reunieran en reducciones...» «...a quienes yo inducía a hacer lo que les resultaría más conveniente; a comprender lo malo que sería que los repartieran por piezas, no por familias, como iba a suceder si se negaban a abandonar el valle...». ${ }^{22}$

Sin embargo algunos grupos como los paccioca - con sus parcialidades de Tolombón y Colalao - fueron autorizados, al menos por un tiempo, a quedarse en el valle Calchaquí, aunque no precisamente en sus asentamientos originarios. Por el hecho de haber colaborado con los españoles se hallaban temerosos de las represalias de las otras naciones rebeldes (especialmente los quilme), por lo que el gobernador les sugirió que se mudaran «hacia el norte» donde «habían quedado despobladas muchas tierras fértiles y

21 Torreblanca, H. de: Relación de los sucesos.... fol. 82.

2 L Ibidem, fols. 82-84. 
con aguadas» y así, si los enemigos los atacaban, podrían ser fácilmente defendidos por los vecinos de Salta. ${ }^{23}$

Otras poblaciones, como los chuschagasta, fueron inmediatamente trasladados al valle de Choromoros. En 1660 «la mitad del pueblo de Chuchagasta» se encuentra ubicado en la estancia de Antonio de Aragón, a quien han sido entregados en encomienda. ${ }^{24}$

Mientras tanto, en el valle de Calchaquí la represalia contra los paccioca no se hizo esperar: «...los acometieron los demás indios rebeldes y a la mayor parte de ellos los arruinaron, mataron y destruyeron...». ${ }^{25} \mathrm{La}$ venganza de los paccioca fue peor. En ocasión que los quilme y sus aliados, por falta de alimentos, quisieron hacer amistad con ellos «los atacaron por sorpresa y mataron a muchos, sobre todo mujeres» y luego, bien abastecidos, se fueron a Salta a ponerse bajo la protección de los españoles. Allí permanecieron hasta el segundo gobierno de Alonso de Mercado, oportunidad en que, incorporados nuevamente a los ejércitos españoles, reiniciaron la guerra «y amparados por nuestros soldados les hicieron a sus enemigos todo el daño posible».

La rivalidad entre los grupos aborígenes del valle se evidencia en la fragilidad de las alianzas que establecían entre ellos o con los españoles para enfrentarse a unos o a otros. Es seguro que entre esos grupos habría diferencias tanto sociales como culturales - según lo ha demostrado la arqueología - y las jefaturas más abarcativas (ocho o doce pueblos a lo sumo) sólo corresponderían a eventuales caciques o curacas «principales» que lograban convocar a todas las parcialidades bajo su jefatura para la conducción de la guerra, como ocurrió con Juan Calchaquí.

Es probable que esas rivalidades hubieran tenido su origen en las diferencias existentes entre los antiguos grupos étnicos pobladores del valle y los que habrían ido ingresando con el tiempo.

23 Ibidem, fol. 85.

24 A.H.T., Secc. Administr., vol. 1; fols. 80vto. y 149-152. En: Lizondo Borda. M.: Documentos coloniales..., Serie I, vol. IV, documentos núms. IV y XIV.

25 Informes de los gobernadores Cabrera y Figueroa, del año 1662, sobre la guerra calchaquí. En: Larrouy, P.: Documentos..., docum. núm. XXX. 
No podemos olvidar que el valle Calchaquí se había convertido, desde el comienzo de la ocupación española del Noroeste argentino, en el único lugar de refugio de los aborígenes no encomendados o de aquellos que lograban escapar de las obligaciones que les imponía el sistema colonial. Aparentemente las rivalidades surgidas entre algunos de esos nuevos grupos y los que secularmente habían vivido en el valle condicionaría las alianzas.

Lo que sí es evidente es la existencia de una atomización política que dentro del valle le permite a cada etnia actuar con bastante independencia y flexibilidad para acordar alianzas con otras parcialidades o con los españoles.

En 1665 se inicia la campaña definitiva contra el valle Calchaquí cuyo saldo fue la desnaturalización de las parcialidades que aún se encontraban residiendo allí, especialmente los Quilme y Acalián. La suerte de los Tolombón y Colalao en este caso, no fue diferente de los demás: también fueron divididos y desnaturalizados. Pero para ellos se adquirieron tierras en Choromoros. ${ }^{26}$

Divididos en tercios - según se aprecia en los padrones de las últimas décadas del siglo XVII - tolombones y colalaos fueron encomendados a vecinos de Salta y San Miguel de Tucumán, con la obligación de cumplir «mita de plaza» en Esteco, fundamentalmente para su defensa militar.

b) Su cuolución demográfica

Para llevar a cabo el análisis de la evolución demográfica de estas poblaciones, las condiciones de su relocalización, así como de las obligaciones a que estuvieron sujetos dentro de la estructura colonial y las probables respuestas adaptativas a su nuevo hábitat, contamos, como dijimos antes, con el empadronamiento general de 1673 y la visita general de 1692, además de los restringidos a la jurisdicción de San Miguel (padrones de 1688,

26 Torreblanca, I'.: Relación de los sucesos..., fols. 149-150. 
1711 y 1718). Las fuentes de carácter circunstancial, como las visitas e informes eclesiásticos sobre el curato de Choromoros y algunos documentos administrativos y judiciales nos permitieron por otra parte complementar los datos para componer los cuadros demográficos. ${ }^{27}$

Debemos considerar que para este período, cuando de análisis demográfico se trata, hay que evaluar la pertinencia de los instrumentos de cuantificación que se conservan ya que de hecho, los abusos o negligencias cometidos por los agentes intermedios involucrados en los censos (alcaldes, fiscales, curacas y encomenderos), afectan directamente los recuentos poblacionales pues no pocas veces incurren en fraude censal.

El documento más antiguo que revela la situación de las parcialidades calchaquíes extrañadas a Choromoros es un padrón parcial correspondiente a la jurisdicción de Esteco, del año $1671 .^{28}$ Se limita al recuento de los indígenas de las encomiendas de Juan Martínez de Iriarte y de Pedro Martínez de Pastrana, ambas del pueblo de Tolombón. Aparentemente eran parcialidades de una misma entidad étnica, como puede apreciarse por el hecho de que ambas tienen un mismo cacique (ver apéndice, cuadro II). Según se establece por este mismo documento la mita que debían cumplir estas poblaciones consistía en «atender las sementeras y cría de ganado de los vecinos de Esteco y defender la ciudad de las invasiones y hostilidades que el enemigo fronterizo hace de ordinario». Para ello los curacas y alcaldes debían asistir a dicha ciudad puntualmente con «todos los indios que tocaren a la sexta parte», "a los cuales se les pagará su servicio personal en su mano, habiendo cumplido con su obligación se muden y vuelvan a sus reducciones». ${ }^{29}$

En la relación de encomiendas y padrones de indios realizada en 1673, los grupos establecidos en Choromoros aparecen discri-

27 Los padrones de indios encomendados en la jurisdicción de San Miguel de Tucumán han sido publicados por Lizondo Borda, Documentos coloniales..., Serie I, vol. V, docum. núm. IV y vol. VI, docum. núm. VI.

28 Archivo Nacional de Bolivia (Sucre), tomo I, 1673. A.G.I., Charcas, 52. Padrón de indios de Esteco en la provincia de Tucumán.

29 Ibidem. 
minados en la siguiente forma: pueblo de Tolombón, encomendado en dos tercios; pueblo de Colalao, encomendado en cuatro tercios, y pueblo de Chuschagasta, encomendado en dos tercios (ver apéndice, cuadro III). Todas las parcialidades tenían su asiento en cl valle de Choromoros, compartiendo probablemente sus asentamientos con otras etnias en las estancias de los feudatarios.

En cuanto a los padrones de indios de la jurisdicción de San Miguel de Tucumán de 1688 , éstos fueron realizados con el propósito de actualizar las cargas fiscales de los encomenderos. Es por ello que los datos referentes a las tareas a que estaban sujetas las comunidades indígenas en las distintas estancias, son muy exiguos. Por otro lado, en este testimonio no aparecen registradas todas las parcialidades que se mencionaron en el padrón de 1673, con lo que se dificulta establecer una relación demográfica entre ellos (ver apéndice, cuadro IV).

Para 1692 contamos con dos fuentes documentales que registran los pueblos aborígenes residentes en el valle de Choromoros: por un lado, la visita que realiza a la gobernación del Tucumán, el oidor de la Audiencia de La Plata don Antonio Martínez Luján de Vargas, y por otro la relación del curato de Choromoros que hiciera Alonso Ruiz de Marañón, cura beneficiario de las doctrinas de Colalao, Tolombón y Chuchagasta. ${ }^{30} \mathrm{~A}$ pesar de que ambos testimonios corresponden al mismo año, no consignan los mismos datos (ver apéndice, cuadros $\mathrm{V}$ y VI).

Los motivos que habían ocasionado la visita de Luján de Vargas fueron esencialmente los abusos de que eran objeto los indios por parte de los encomenderos tucumanos, a pesar de las leyes y ordenanzas vigentes. Esta situación, denunciada en varias ocasiones en la segunda mitad del siglo, sólo fue atendida luego de la solicitud presentada por el obispo de Tucumán fray Nicolás de Ulloa, quien expresaba cuán necesaria era la visita de esta gobernación pues los encomenderos no sólo cobraban tributos de los indios, sino también de sus mujeres, teniéndolos generalmente peor que

30 Descripción de dieciocho curatos del Tucumán. En: Larrouy, P. A.: Documentos..., docum. núm. XXXIX. 
esclavos, siendo la principal consecuencia de ello el deterioro y destrucción de las encomiendas.

Si bien la visita de Martínez Luján de Vargas ha sido transcrita por Doucet y González Rodríguez, nosotros podemos añadir algo más a la misma, para lo que hemos optado, en unos casos, y completado, en otros, las cifras dadas por cada uno de ellos, siguiendo el criterio metodológico que consideramos más adecuado. "

Ambos investigadores comentan las características peculiares de esta visita. En general parece ser que el procedimiento empleado por el visitador fue, no el de dirigirse personalmente a cada reducción de indios para levantar el padrón, sino que prefirió señalar determinados lugares donde debían comparecer los vecinos feudatarios $y$ sus encomendados. Los lugares elegidos para ello fueron en su mayoría las ciudades cabeceras de cada jurisdicción, y los argumentos esgrimidos por Luján de Vargas apuntaban a la dificultad de trasladarse a cada una de las reducciones, debido a la dispersión que ellas sufrían como producto de que buena parte de los indios no vivían en pueblos, sino en las haciendas de sus encomenderos. Si bien es cierto que esta modalidad de la visita fue la aplicada en la jurisdicción de San Miguel (para lo cual se eligió a la ciudad y la estancia de Miguel de Vera, en el curato de Choromoros), no se debe desconocer que algunos pueblos fueron visitados personalmente por el oidor, como ocurrió con todos los de Salta, La Rioja y algunos repartimientos de Córdoba.

El procedimiento empleado para el empadronamiento de los aborígenes le quita a esta visita cierta precisión y fiabilidad para ser utilizada como fuente demográfica. Sin embargo, con los recaudos de crítica necesarios, podemos valernos de estas cifras como una aproximación a la realidad.

A pesar que para las poblaciones aborígenes que en nuestro trabajo se analizan los valores transcritos por Doucet y González. Rodríguez en general no varían (ver apéndice, cuadro V), hemos comienda...

31 Doucet, G.: Introducción al estudio... y González Rodríguez: La en- 
seguido fundamentalmente las de este último por encontrar su criterio metodológico más adecuado a la situación por nosotros descrita. Así mientras Doucet limita los padrones al número de tributarios que contienen (tanto los presentes como los ausentes), González Rodríguez incluye además a los curacas, reservados, mujeres, viudas y los muchachos y muchachas no tributarios. Ello, a nuestro modo de ver, da una idea más completa desde el punto de vista demográfico. Por otro lado, en el caso de no contar con todos los datos consignados anteriormente, como ocurre con el repartimiento de Chuscha, administrado por José de Ovejero, González Rodríguez aclara que ello corresponde al número de indios examinados por el visitador y no al empadronamiento general. Sí hemos tomado de Doucet el nombre de la encomienda de Anganomo - no consignado por González - pues hemos podido comprobar por otros testimonios que este repartimiento se venía sucediendo en la familia desde la merced que se hiciera en primera vida a don Juan Martínez de Iriarte, tío por vía materna de don Juan de Palacios (menor en 1692), quien ostenta la encomienda en esos momentos. ${ }^{32}$

Cotejadas las cifras contenidas por los padrones de la visita general de Luján de Vargas, con las consignadas para la misma fecha de 1692, por la declaración del cura de la doctrina de Choromoros, don Alonso Ruiz de Marañón, en ocasión de la descripción de los curatos del Tucumán, notamos cierta disparidad. Pero este último testimonio tampoco es de mucha utilidad desde el punto de vista demográfico, pues allí únicamente se consignan los indios tributarios.

Otro testimonio al que hemos tenido acceso, pero que es bastante parcial, es el padrón correspondiente a los indios del pueblo de Tolombón del año $1700 .{ }^{33}$ En realidad en esta oportunidad no se empadrona a las diferentes parcialidades de este pueblo, las cuales estaban divididas en tres repartimientos, sino únicamente a la que perteneciera al maestre de campo don Pedro Martínez de

32 Ver nota núm. 18 de este Irabajo.

33 A.H.T., Sección Administr., vol. II, fols. 442-446v. Padrón de los indios del Pueblo de Tolombón. 
Pastrana «difunto encomendero que fue de la dicha Encomienda» y que ahora pertenecen al capitán Pedro Ruiz de Villegas, y a la correspondiente a Pedro Martínez de Iriarte «Encomendero de la mitad de dicho Pueblo de Tolombón». La finalidad de este empadronamiento era, no sólo la de actualizar las cifras de indios de tasa por los que sus encomenderos eran deudores al fisco, sino también la de averiguar «de los indios que faltaren de dicho Pueblo y si los encomenderos a quien se encomendaron los tienen en esta dicha reducción y pueblo de Tolombón o los han sacado a otra parte con tropas de mulas». El empadronamiento se lleva a cabo en el mismo pueblo de Tolombón, en el valle de Choromoros, y allí se consignan, además del curaca y el alcalde de la población, los indios de tasa, los reservados de tasa ausentes, las mujeres, niños (varones y mujeres) y los huérfanos, cada uno de ellos con la especificación de su edad y estado civil. Las dos encomiendas (mitades) han sido registradas juntas, pero en un apartado se consignan a los «tasa ausentes» llevados por el capitán Ruiz de Villegas en su viaje al Perú, los que suman diez indios de los tributarios ausentes. Al final del empadronamiento se aclara «que lo que toca a los indios ladinos anejos a este Pueblo que obtuvo Martínez de Pastrana se hallan en la ciudad de Salta y no están aqui».

Finalmente contamos con los padrones de indios de la jurisdicción confeccionados por orden del gobernador Urízar y Arepacochaga para precisar el número de indios que debían cumplir con las mitas y corresponden a principios del siglo XVIII (1711-1718). Aquí, las poblaciones aborígenes encomendadas en el valle de Choromoros no se registran. Es muy probable que estos indígenas fueran asignados a realizar prestaciones militares en el presidio de Balbuena - próximo a la ciudad de Esteco- para evitar las invasiones chaqueñas que asolaban la región. De ser así, es posible que se eximiera a los encomenderos de cumplir con la contribución correspondiente a los indios recién incorporados a la tasa.

Según se podrá apreciar por los cuadros del apéndice, hay un evidente descenso demográfico en las encomiendas del valle, lo que a su vez marca la tendencia general del proceso sufrido por 
las poblaciones aborígenes de la jurisdicción de San Miguel. Sin embargo, no se puede establecer una relación directa de mortalidad, al menos para los tributarios, aunque sí es factible para la población infantil. También el índice de natalidad evidencia haber disminuido. Claro ejemplo de ello es la encomienda de Tolombón de Martínez de Iriarte: manifiesta una disminución de un $25 \%$ en los tributarios y de un $35 \%$ y un $60 \%$ en los menores de dieciocho años (varones y mujeres) durante los veinte años transcurridos entre $1671 / 1673$ y 1692 . Sin embargo, en lo que atañe a los primeros es probable que su disminución obedezca a un ocultamiento de los individuos para reducir la tasa que debía pagar el encomendero.

También es evidente que hay un subregistro en el censo correspondiente a la encomienda del pueblo de Tolombón, perteneciente a Martínez de Pastrana, que consigna cinco tributarios en el padrón realizado en 1671 y casi cuarenta en 1673. Esta última cifra se mantiene más o menos constante hasta fines del siglo XVIII, cuando ya ha pasado como encomienda del capitán Ruiz de Villegas, pero donde también se establece que este repartimiento se componía de un número indefinido (pues no se consigna en el padrón de 1700) de indios ladinos, es decir de indios ajenos al pueblo de Tolombón y que corresponderían a otro repartimiento que le había sido adjudicado a Pastrana. Aquí conviene hacer una aclaración con respecto a la denominación de indios ladinos, muchas veces registrados en los empadronamientos analizados. Bajo esta catalogación se han incluido en general a antiguos repartimientos, que provienen de las llanuras, es decir que no son indios serranos, han sido encomendados desde el comienzo de la colonización del territorio y «hablan la lengua general» por lo que no necesitan intérpretes. Lamentablemente la falta de datos testimoniales nos impide identificar específicamente al repartimiento de indios ladinos de Pastrana.

Un poco más difícil de explicar es la situación de la encomienda de Colalao de Díaz Zambrano, que entre 1673 y 1688 ha aumentado el número de tributarios, aunque el resto de la población evidencia un marcado descenso. Quizá un buen número de 
varones que en 1673 no tributaban haya accedido a la categoria de indios de tasa. En el caso de las mujeres, manifiestan un descenso de alrededor del $50 \%$, pero tampoco podemos atribuirlo exclusivamente a la mortalidad considerando que en varios testimonios ni siquiera se registran.

Con respecto a la encomienda de Colalao, de Avila y Zárate, pertenecía, por herencia, a su mujer Claudia Costilla, viuda de Bernardo Ordóñez de Villaquirán. A diferencia de las otras encomiendas registradas, evidencia un aumento importante de tributarios, cuyas razones podríamos encontrarlas en la anexión del pueblo de Colalao con indios tafíes, solcos y lules, que también eran encomienda de Avila y Zárate. Ello provocaría seguramente una mayor descomposición étnica en los grupos. En 1689 se registran los indios tafíes, que a su vez conviven con solcos y lules, como «indios que están en el pueblo de Colalao y Tolombón que así mismo pertenecen a este dicho pueblo», muchos de ellos «casados en el dicho pueblo». ${ }^{34}$ Cuando Zárate, a quien se le obliga a elegir entre las encomiendas que tiene, elige el pueblo de Tafí y quiere rescatar a sus indios, expresa: que los indios contraviniendo las órdenes que les prohíben volver al valle Calchaquí «se van poblando» allí y no se devuelven «por pertenecer los dichos indios al pueblo de Colalao». Invocando para justificar su petición una «real cédula de la nueva Recopilación de leyes» que hace referencia, exactamente, a la no separación de los pueblos de indios o a su división ${ }^{35}$ evidenciándose, en consecuencia que los encomenderos tenían un exacto conocimiento de la legislación vigente, aunque en la práctica - cuando sus intereses así lo requerían - no la aplicaran.

Finalmente en la encomienda del pueblo de Chuschagasta, de Antonio de Aragón, se mantiene casi sin variantes a lo largo del período analizado, e inclusive presenta un pequeño incremento entre la población infantil y adolescente (varones $21 \%$, mujeres $23 \%)$. En cambio el número de las mujeres adultas es muy bajo y su incremento hacia finales del siglo quizá obedeciera a la incorporación de población femenina de otros pueblos.

34 Lizondo: Documentos coloniales..., doc. XXXV.

35 Recopilación de Leyes de los Reinos de Indias, Lib. VI, tit. 8, Ley 22. 


\section{Algunos efectos de extrañamiento}

No se puede pensar que el valle Calchaquí se hubiera mantenido hasta la segunda mitad del siglo XVII, como una «isla» sin contacto alguno con la cultura europea. Varias fundaciones españolas habían tenido lugar en el territorio y aunque en general fueron efímeras, habían ido produciendo en sus poblaciones indígenas un lento proceso de cambios culturales.

Sin embargo los traslados organizados por Mercado y Villacorta en 1659 y 1665 no implican sólo un cambio de hábitat para la totalidad de las comunidades aborígenes del valle, sino que desde el punto de vista de los grupos humanos afectados, la desnaturalización apuntaba a la destrucción del nicho original, a aflojar los vínculos grupales, adecuarlos a otro espacio donde su subsistencia y producción se encontrarán condicionadas desde una organización ajena al grupo. Ello provocó las bruscas caídas demográficas comentadas anteriormente y un cambio absoluto en sus modos de producción, reproducción, organización social, creencias religiosas y usos lingüísticos.

Desde el punto de vista de su organización social, poblaciones como los tolombón y los colalao conservaron sus caciques, aparentemente de carácter hereditario y con una relativa extensión que incluiría al menos dos parcialidades. Sin embargo, no creemos que hayan llegado a convertirse en los articuladores de las dos sociedades en pugna, antes bien se mantuvieron en una actitud de franca rebeldía y cuando les era posible eludían y hacían eludir las cargas que sobre ellos y sus comunidades pesaban en el mundo colonial. ${ }^{30}$ A esas jefaturas naturales se sumaron - cuando los grupos fueron extrañados y localizados en el valle de Choromoros- al menos dos autoridades más, esta vez producto de su «reducción» a pucblos: el alcalde y el fiscal. Encargados de administrar justicia entre los aborígenes $\mathrm{o}$ de conducirlos ante los tribunales españoles $y$

36 A.H.T., Sección Judic., Serie A, expte. 37, caja 23, año 1770. 
de ejercer control fiscal sobre la población, vinieron a trastocar el sentido de autoridad de lo organización social indígena.

En cuanto al sistema de producción originario de estas comunidades, en general deben haber respondido al patrón andino. Ello consistía básicamente en una econornía agrícola —realizada en colaboración por todos los miembros de la familia- y una actividad ganadera y pastoril con animales propios de la zona y mediante la práctica de la trashumancia. Su alimentación se complementaría con la caza y recolección de frutos silvestres. El cambio hacia una producción no destinada ya a la supervivencia de la comunidad, sino relacionada con el abastecimiento de los mercados locales y regionales de la Colonia, provocó una ruptura de los mecanismos sociales en las comunidades. Los hombres debieron dedicarse al cuidado de las sementeras de los encomenderos, cumplir con la mita de plaza en Esteco o en la ciudad de San Miguel, o preocuparse de la cría, invernada y traslado del ganado de los hacendados tucumanos. Estas actividades los mantenían por largas temporadas fuera del pueblo y lejos de sus familias. Ello se evidencia en el marcado absentismo registrado en los padrones.

La descomposición de las unidades familiares redundaba en detrimento de su producción comunal y la reproducción y crecimiento del grupo. El pueblo de Tolombón, de la encomienda de Juan Martínez de Iriarte, cuenta con un absentismo de tributarios (la población masculina más productiva) superior al $35 \%$ que se encuentra fuera de la reducción cumpliendo tareas que, aunque no se especifican, fueron encargadas por el mismo encomendero. $\mathrm{Mu}$ chos de ellos están en las jurisdicciones de Jujuy, Guachipas, Córdoba y varios de ellos en el Perú (padrón de 1671). La encomienda de Díaz Zambrano, del pueblo de Colalao, cumple servicio personal en la estancia de su encomendero que tiene su ubicación en la jurisdicción de Salta. Muchos de los aborígenes de este pueblo se han casado con mujeres de la zona. Si ese absentismo, en principio temporal, se convertía en permanente - por muerte, huida o nuevo casamiento del tributario-, la desestructuración familiar era total: las mujeres y los niños quedaban solos. 
La disolución de la únidad étnica también se evidencia en la laxitud de algunas costumbres de los grupos, como por ejemplo, en el matrimonio que produce uniones interétnicas entre las distintas parcialidades (tolombones y chuschagastas, o colalaos y tolombones, aunque estos últimos parecen haber pertenecido a una misma etnia). Otras veces las uniones se realizaban con integrantes de diferentes etnias, en algunos casos «a la usanza» de uno de los grupos y en desmedro de las costumbres del otro.

Así como la pérdida de la identidad étnica de estas parcialidades era a fines del siglo XVII casi un hecho, ciertas pautas cul turales se sumían en un sincretismo religioso y lingüístico. El resquicio para la pervivencia de algunas costumbres se encontró a través de las idolatrías, las supersticiones, mitos y leyendas populares y mediante la persistencia de lenguas o dialectos propios, al menos hasta fines del siglo XVII. ${ }^{37}$

Otro factor que tuvo gran importancia sobre la suerte del proceso demográfico indígena fue la pérdida de sus propiedades territoriales comunales, pues hizo más precaria su situación y condiciones de supervivencia. Los indios eran considerados para el derecho como personas necesitadas de protección y tutela para todos sus actos (desde producir y reproducirse hasta enajenar sus bienes) y por ello fueron amparados en los derechos sobre sus tierras comunales, las cuales permanecieron - para la legislación - con carácter inalienable. Sin embargo estas propiedades tampoco se libraron de la ambición de los encomenderos, como se ha podido comprobar al menos para los siglos XVI y XVII. ${ }^{38}$

Si la legislación hispana contempló todos los casos posibles de las relaciones español-aborígen, en la práctica la realidad indígena hacia fines del siglo XVII se desdibujaba, asumiendo caracteres de rebelión en unos casos o de aparente sincretismo en otros. El re-

37 En todos los padrones de las poblaciones aborigenes que se conservan para el período, esas poblaciones necesitaban de un intérprete para entender las preguntas que se les hacen. Esto se mantiene aún en el siglo XVIII.

38 Este tema ha sido desarrollado en parte para el siglo XVI y XVII en todo el ámbito de la jurisdicción de San Miguel de Tucumán en el trabajo de López de Albornoz, Cristina: El derecho a las tierras en la jurisdicción de San Miouel, a la luz de la documentación del siglo XVI y XVII (en prensa). 
sultado de todos modos fue la formación de un estamento social indiscriminado - el mestizo - que a principios del siglo XVIII parece haber asumido una actitud ontológica sobre su condición de desprotegido y marginado de la sociedad colonial.

\section{Conclusiones}

La violencia social es inseparable de una sociedad que descansa sobre el trabajo esclavo o semiesclavo y donde el privilegio decide la suerte de muchos individuos y algunos grupos. Sin embargo, esa violencia social - que no sólo caracteriza a la relación dominador-dominado sino también a grupos sociales de pareja condición social- asume las expresiones más dramáticas cuando estalla una insurrección o cuando se sospecha que puede estallar. Es cuinndo todo castigo parece poco para que sirva de alerta a otros qui pueden sufrir el contagio de la rebeldía.

La extinción prácticamente total de los núcleos aborígenes registrados a principios del siglo XVII debió responder, en general, a un estadio cultural menos avanzado que les habría condicionado a padecer con mayor intensidad el nuevo modo de vida impuesto por el sistema colonial. La falta de una estructura social organizada les hizo más vulnerables a los procesos desestabilizantes de la unidad comunal y familiar.

A pesar de que las circunstancias de los pueblos encomendados se mantienen aún hasta el fin de la colonia, se observa que existe cierta adecuación a ellas de parte de las comunidades extrañadas del valle Calchaquí -comunidades culturalmente más desarrolladas - las cuales, aunque diezmadas, lograron llegar al fin del período conformando pueblos indígenas más o menos definidos.

La visita que por las denuncias por malos tratos a los aborígenes tucumanos realizara Martínez Luján de Vargas no parece que haya producido efectos considerables sobre la situación de las encomiendas.

Hacia fines del siglo XVIII varias son las encomiendas de pueblos indios ladinos y desnaturalizados que sobreviven bajo 
las mismas condiciones. En 1770 el cacique de los indios de Tolombón denuncia a la autoridad local los malos tratos a los que los somete su encomendero, que además no les da de comer ni con qué vestirse, trasquila a sus mujeres y las azota. Por otro lado, no los ha reducido a pueblo y por ello carecen de doctrina. Mediante este expediente los indígenas solicitan tributar al Rey, no mitar a la ciudad de San Miguel — de la cual se hallaban muy alejados- sino a la villa de San Joaquín de Las Trancas, y además, piden el reconocimiento de sus tierras «por hallarnos oprimidos de los Españoles circunvecinos que se nos quieren introducir y desposeer de nuestro derecho y acción». ${ }^{39}$

Varios pueblos indígenas de la jurisdicción de San Miguel llegan encomendados hasta fines del siglo XVIII, aunque reducidos a unas pocas familias o unos pocos indios tributarios, $y$ todos ellos siguen estando sujetos a tipos de explotación similares a los del siglo XVI.

Siendo el pilar fundamental de la subsistencia de la región la encomienda, ésta fue defendida en su vigencia hasta fines del siglo XVIII. Así cuando para toda América hispana la extinción de la encomienda se reglamentaba por la real cédula de 1720 , Tucumán quedaba eximida por el mismo expediente pues la región respondía a la excepción que aquí se contemplaba: «la incorporación de aquellas encomiendas que fuesen de servicio personal, siempre que éste fuese cambiado por el cobro del tributo o se convirtiese en un servicio voluntario que los indios ejecutasen para facilitar el pago del mismo». A pesar de una nueva cédula real, fechada en diciembre de 1771, que establecía que «cumplidas las vidas que estuvieran concedidas las encomiendas debían integrarse en las de la Real Corona», algunas encomiendas tucumanas se mantuvieron vigentes hasta comienzos del XIX. ${ }^{40}$

\section{Cristina lópez de Albornoz}

39 A.H.T., Sección Judic. Civil, Serie A, expte. 37, caja 23, año 1770.

40 Reales cédulas del 6 de setiembre de 1720 , del 2 de noviembre de 1733 y del 4 de diciembre de 1771, respectivamente. Citado por González Rodriguez, A.: La encomienda..., págs. 194-195. 


\title{
APENDICE
}

\author{
Cuadro I
}

\section{ESTADO DE LA POBLACION CALCHAQUI (LUEGO DESNATURALIZADA A CHOROMOROS) \\ SEGUN RELACION HECHA POR PEIRO BOHORQUEZ EN 1657}

$$
\text { Indios de Armas Total }
$$
Chucagasta ( sic)
70
300
Parcialidades de Talampun y Colalao (sic)
300
1.500

Fuente: A.G.I., Charcas, 121. (Cit. González Rodriguez, La Encomienda..., pág. 27). 


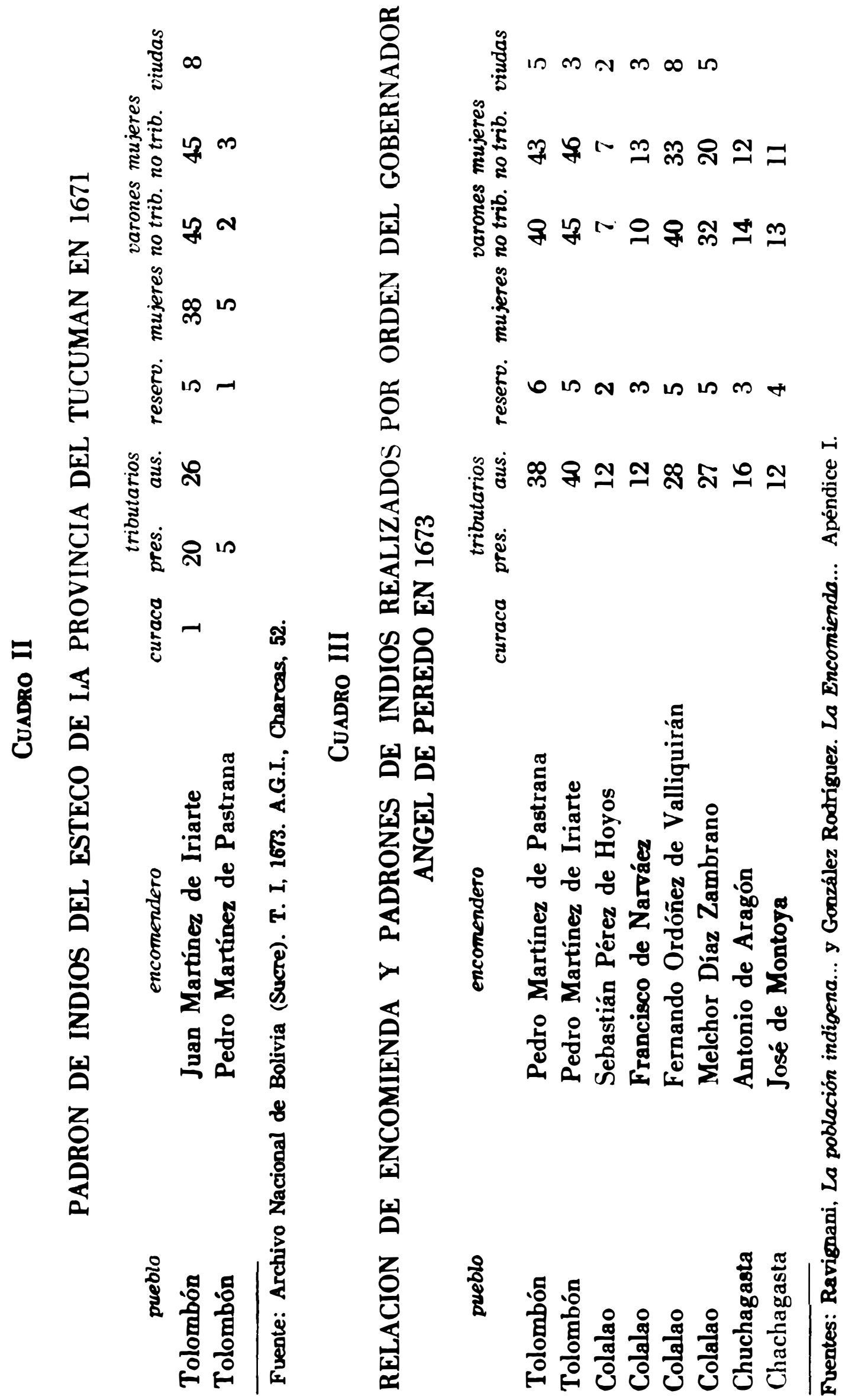



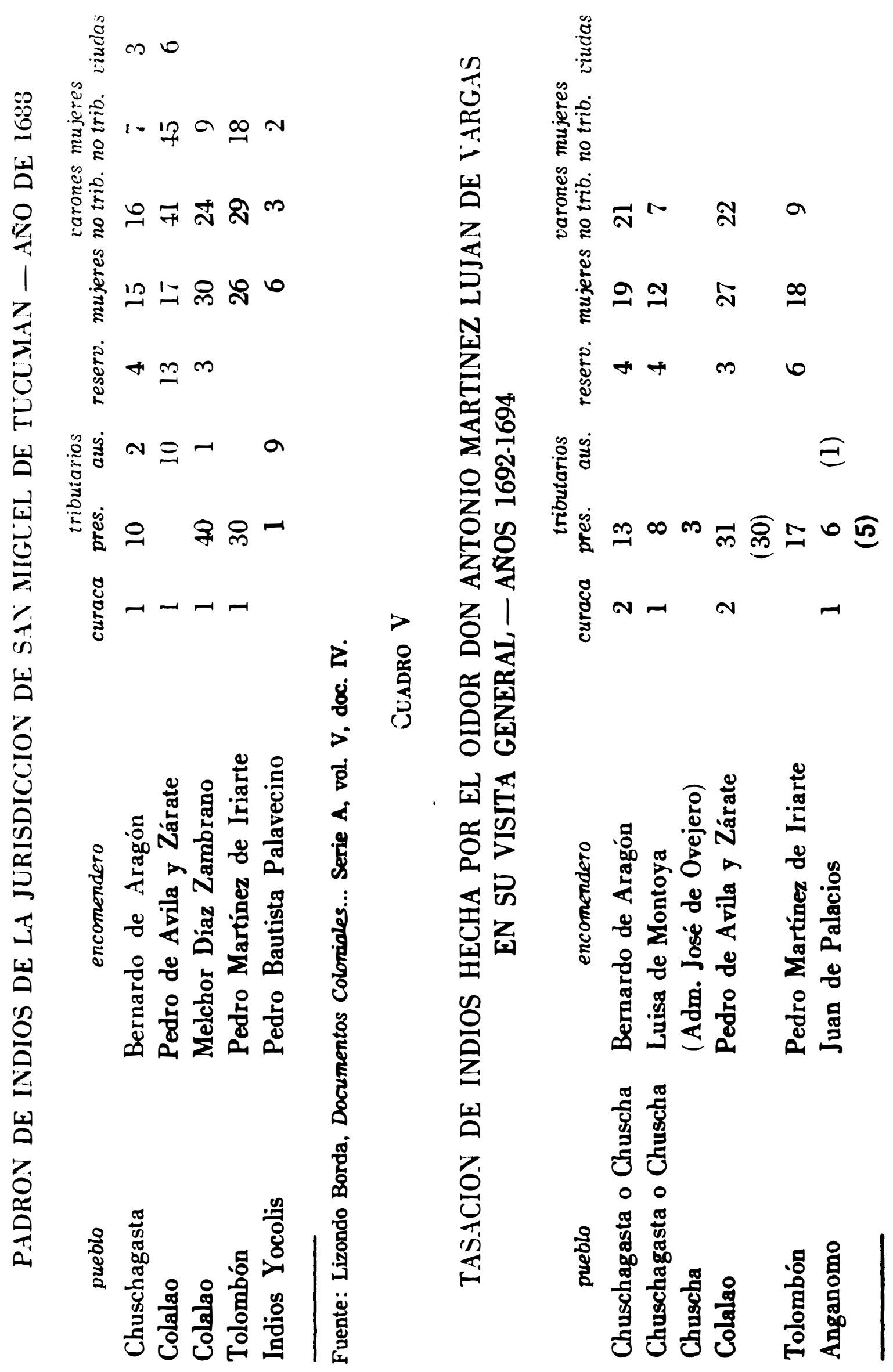

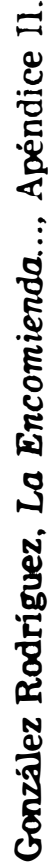

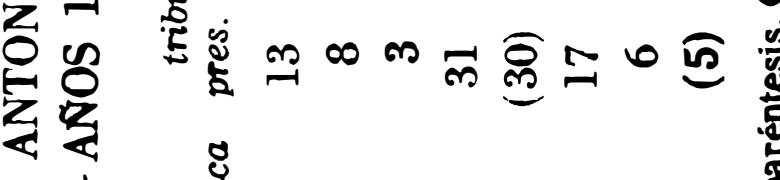

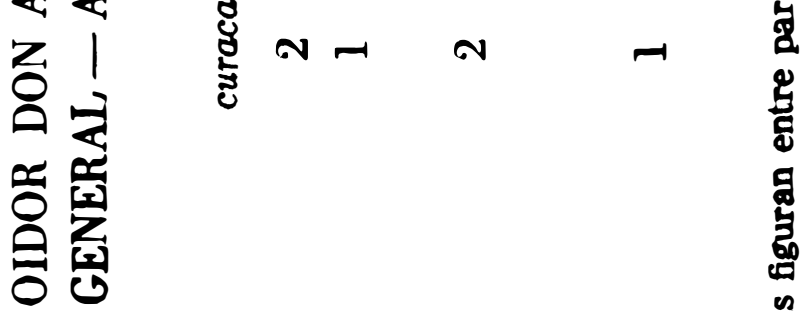

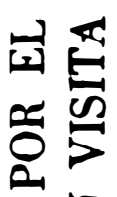

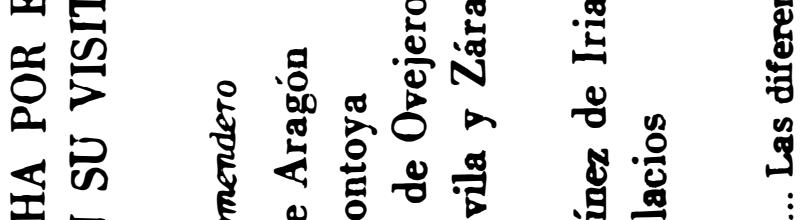

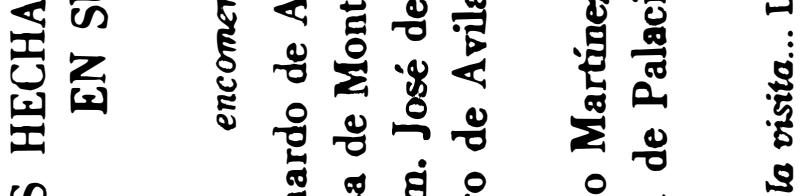

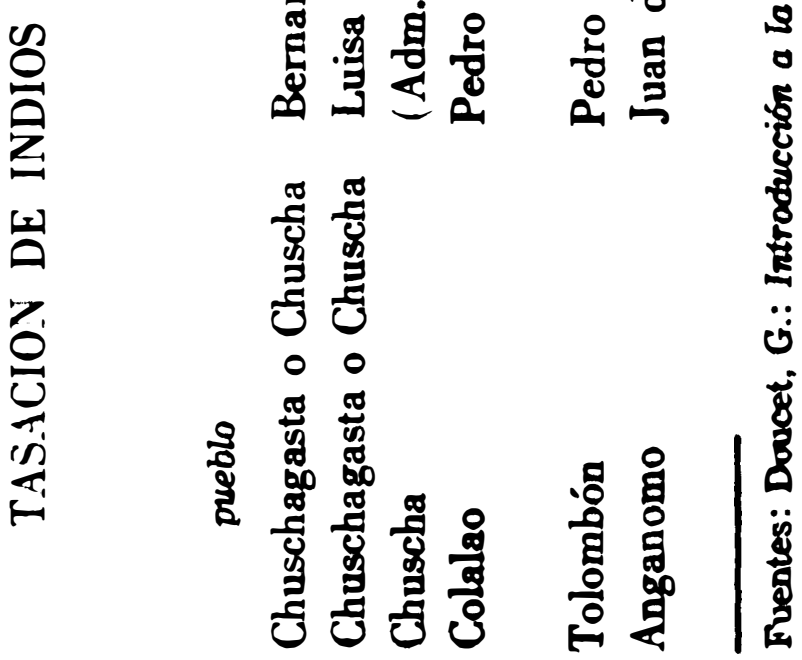

(c) Consejo Superior de Investigaciones Científicas

http://estudiosamericanos.revistas.csic.es 


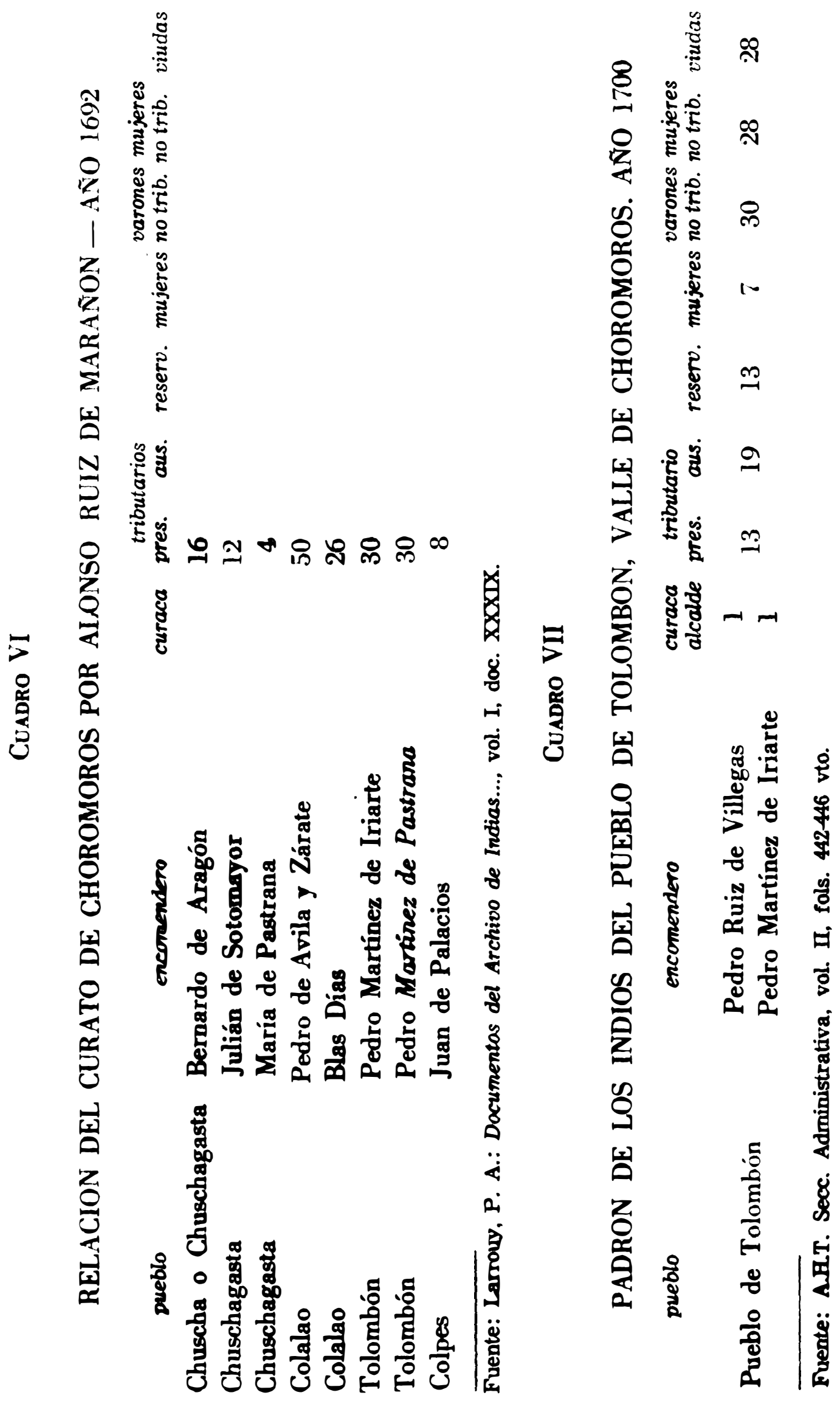

